\title{
Maria Gaetana Agnesi
}

1718-1799

\section{Della Dumbaugh}

On March 8, 2018, the government of Italy issued a set of four stamps celebrating what they described as "Italian Female Genius: Depicting Italian Women who have Distinguished Themselves in the Arts, Sciences \& Culture." Among the four women celebrated was Maria Gaetana Agnesi, described in the announcement as a "mathematician." 1 On September 6, 2018, the Vatican issued a stamp of Maria Agnesi in the category of "Science and Faith." 2 Both stamps commemorate the 300th anniversary of Agnesi's birth on May 16, 1718 and call attention to the two main aspects of her life: the intellectual and the pious.

The first child of a prosperous Italian family, Agnesi's father hoped to advance in social circles in part by educating and exhibiting the education of his children to Milanese society. From an early age, multiple tutors, mostly from religious orders, fostered Agnesi's knowledge and faith within the broader purview of the Catholic Enlightenment (Mazzotti, 2001, 2008; Petrunic). Agnesi was recognized as a child prodigy by the age of five owing in part to her proficiency with languages. Although shy by nature, she joined in the seminars and discussions that took place in her family home in the evenings.

In 1738, at the age of 20, she published her Philosophical Propositions, which included 191 propositions that she purportedly debated with leading scholars. A decade later,

Della Dumbaugh is a professor of mathematics at the University of Richmond and an associate editor of the Notices. Her email is ddumbaugh arichmond.edu.

${ }^{1}$ See www.virginstamps.com/browse_item.htm1? category_id=3123\&item_id=16835\&page=80.

${ }^{2}$ See www. vaticanstate.va/content/vaticanstate /en/servizi/ufficio-filatelico-e-numismatico /emissioni-filateliche/ultime-emissioni/scienza -e-fede-maria-gaetana-agnesi-padre-angelo-secchi .htm1.

For permission to reprint this article, please contact: reprint -permission@ams.org.

DOI: https://dx.doi.org/10.1090/noti 1827 she published her Analytical Institutions for the Use of Italian Youth (Instituzioni analitiche ad uso della gioventu italiana), which con t a in ed principles and methods of algebra, geometry, and differential and integral calculus. She wrote in Italian (not Latin) with an eye towards clarity, initially

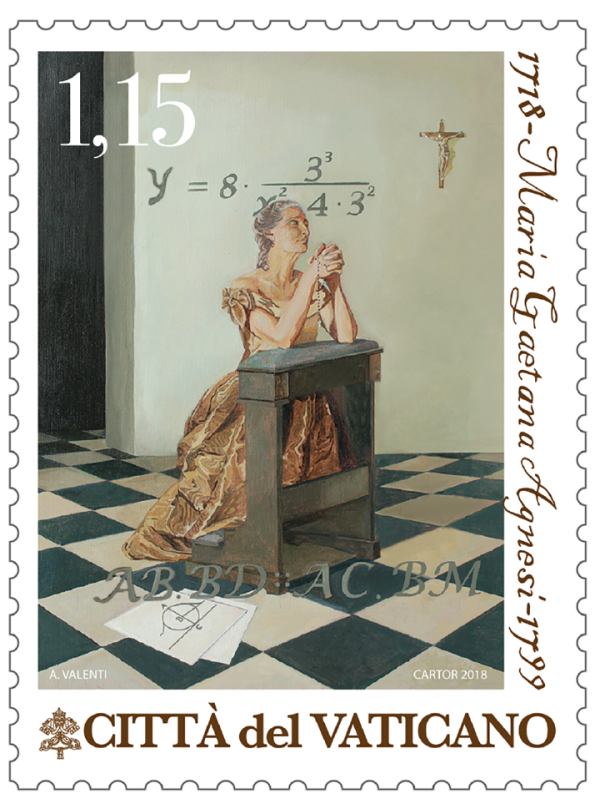
aiming to provide a text for her younger siblings (there were 20 of them, after all). She dedicated the book to Empress Maria Theresa, who expressed her gratitude with diamond jewels. Her family's largess allowed her to print the book on "1044 pages of thick, creamy paper that must have cost her father a pretty penny" (Findlen, 258). Her book garnered the attention of Pope Benedict XIV and earned her an election to the Bologna Academy of Sciences and an appointment to the faculty at the University of Bologna. ${ }^{3}$

Agnesi is best known for the curve that has now come to be known as the "Witch of Agnesi." Modern forms of this curve are given by $y x^{2}=a^{2}(a-\gamma)$ or $y=\frac{a^{3}}{\left(x^{2}+a^{2}\right)}$. This curve did not originate with Agnesi, however, as Pierre de Fermat and Guido Grandi had both studied it. When John Colson, Lucasian Professor of Mathematics at Cambridge,

${ }^{3}$ Despite this appointment, which included her name on the rolls of the university for forty-five years, Agnesi never went to Bologna so she never assumed the duties of this position (Truesdell, 1989, p. 127). 
translated Agnesi's Analytical Institutions before his death in 1760 (published posthumously in 1801), he confused the Italian name of the curve "la versiera," which means "to turn," with "l'aversiera," which means "the witch" or "the she-devil" (Truesdell, 1992, 386; Mazzotti, 2008, 116-117). Both stamps include a sketch of the "witch of Agnesi," although this title is inaccurate both in attributing the figure to her and in its association of her with the notion of a witch.

After her father's death in 1752, Agnesi devoted her life to "great and pious acts of charity" that mostly offered aid to neglected, ill, and aging women (Findlen, 271; Osen, 47). She transformed her home into a refuge for the poor and, when Milan's newest hospital, the Pio Albergo Truvulzio, opened in 1771, she accepted the appointment as director of the women's ward. She hoped to offer women and orphans faith and dignity for a useful life or for the final steps of their earthly journey. Agnesi died in 1799.

In Agnesi's time, as Mazzotti notes, the "intellect was necessary for being a good Christian. If you work[ed] on strengthening your intellect, you [were] doing a good thing for your spiritual life as well" (Lamb). Mazzotti's insight suggests a more holistic view of Agnesi's life, one joined rather than divided by her two primary interests in intellectual and pious pursuits. Reflecting on Agnesi as a woman in mathematics (to use a modern term), Agnesi's family provided her with an education and a chance to study mathematics. She took risks with her Analytical Institutions, writing in Italian and focusing on the mathematics itself, rather than linking it with physical applications as previous texts had done. She also took risks with her father, asking to step back from evening scholarly discourses after her mother died and gradually pursuing more religious studies and activities over time. Findlen may rightly note that Agnesi's life did not follow a "modern trajectory" in that she had the opportunity to do science but then gave "it all up for love of God" (Lamb). But there is something more. Agnesi's life, even at 300 years old, calls attention to some enduring qualities associated with advancing women in mathematics. She had the opportunity to study mathematics, she had educators and family who supported her work, she had a strong enough spirit to take risks, and she received recognition for her work (Fenster \& Parshall, 230). In these ways, the stamps commemorating Agnesi reflect a very modern life.

\section{References}

Maria Gaetana Agnesi Mathematician, 2018 Stamp. www . virginstamps. com/browse_item. htm1?category_id=3123\&item_id=16835\&page $=80$

Fenster Della D, Parshall K, 1994. "Women in the American Mathematical Research Community: 1891-1906" in The History of Modern Mathematics, Volume III, pp. 229-261, edited by David Rowe and John McCleary, San Diego, CA: Academic Press, Inc. 1994.
Findlen P, 2011. "Calculations of faith: mathematics, philosophy, and sanctity in 18th-century Italy (new work on Maria Gaetana Agnesi.)" Historia Mathematica 38: 248-291.

Gray Shirley B, 2018. Review of The World of Maria Gaetana Agnesi, Mathematician of God by Massimo Mazzotti, The Johns Hopkins University Press, Baltimore, MD, 2007. The College Mathematics Journal 49: 229-232.

Lamb E, 2018. "The 18th-Century Lady Mathematician Who Loved Calculus and God." Smithsonian. com. May 16, 2018. https://www.smithsonianmag.com/science-nature/18th-century-1ady-mathematician-who-changed-how-calculus-was-taught-180969078/

Mazzotti M, 2001. "Maria Gaetana Agnesi: Mathematics and the Making of the Catholic Enlightenment." Isis 92: 657683.

Mazzotti M, 2008. The World of Maria Gaetana Agnesi, Mathematician of God. Baltimore: Johns Hopkins University Press.

Osen Lynn M, 1974. "From the Dark Ages to the Renaissance: the 'witch' of Agnesi." In Women in Mathematics by Lynn Osen, 33-48. Cambridge, MA: MIT Press.

Petrunic Josipa G, 2009. "Review of The World of Maria Gaetana Agnesi, Mathematician of God by Massimo Mazzotti." The British Journal of the History of Science 42: 119-121.

"ScienceandFaith:MariaGaetanaAgnesiandFr.AngeloSecchi." www. vaticanstate.va/content/vaticanstate/ en/servizi/ufficio-filatelico-e-numismatico/emissioni-filateliche/ultime-emissioni/scienza-e-fede-maria-gaetana-agnesi-padre-angelo-secchi.html

Truesdell C, 1989. "Maria Gaetana Agnesi." Archive for History of Exact Sciences 40: 113-142.

Truesdell C, 1992. "Corrections and additions for 'Maria Gaetana Agnesi'." Archive for History of Exact Sciences 43: 385-386.

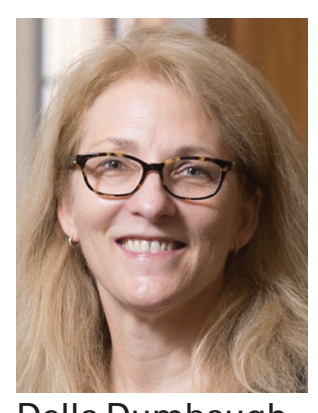

Della Dumbaugh

\section{Credits}

Image of the Agnesi stamp is reprinted here by permission from the Vatican Ufficio Filatelico e Numismatico (Philatelic and Numismatic Office)

Author photo is used by permission of the University of Richmond. 